\title{
EVALUATION OF THE EFFECT OF YOGIC PRACTICES ON RAKTAGATA VATA (ESSENTIAL HYPERTENSION)
}

\begin{abstract}
PRADEEP KUMAR PAL ${ }^{1}$, NEERA SAINI ${ }^{2 *}$, MISHRA VN ${ }^{3}$, AWASTHI HH $^{4}$
${ }^{1}$ Department of Rachana Sharir, Faculty of Ayurveda, IMS, BHU, Varanasi, Uttar Pradesh, India. ${ }^{2}$ Department of Vikriti Vigyan, Dr. Vijay Ayurvedic Medical College, Kaithi Varanasi, Uttar Pradesh, India. ${ }^{3}$ Department of Neurology, IMS, BHU, Varanasi, Uttar Pradesh, India. ${ }^{4}$ Department of Rachana Sharir, Faculty of Ayurveda, IMS, BHU, Varanasi, Uttar Pradesh, India. Email: dr.neerasaini@gmail.com
\end{abstract}

Received: 05 June 2018, Revised and Accepted: 21 July 2018

ABSTRACT

Objective: Essential hypertension is the most frequent kind of hypertension and also known as primary hypertension or idiopathic, affecting $95 \%$ of hypertensive patients. This study was conducted to see the effect of Yogic practices as Nadi Shodhana Pranayama (NSP = cleaning of subtle energy channel along with regulation of rhythm of breathing) and Dhyana (meditation) on the symptoms of Raktagata Vata (essential hypertension), blood pressure, and Hamilton's anxiety rating scale.

Methods: This clinical study was conducted on 50 cases of Raktagata Vata, and these were randomly divided into two subgroups: (1) Control and (2) intervention consisting of 25 cases in each subgroup. Yogic practices were done regularly for 3 months by the registered cases in both subgroups. Light medication of first order initially was also prescribed to intervention subgroup.

Result: In both subgroups, significant results $(\mathrm{p}<0.001)$ were observed and most of the symptoms of Raktagata Vata improved better in the intervention than control subgroup. Significant results $(\mathrm{p}<0.001)$ were also observed in blood pressure along with Hamilton's anxiety scale scoring.

Conclusion: Yogic practices impact positive effects on Agya Chakra (hypothalamus-cerebral system), control autonomic nervous system and improve the quality of life of Raktagata Vata patients by improving symptoms and regulating the blood pressure.

Keywords: Agya Chakra, Yogic practices, Raktagata Vata (essential hypertension).

(C) 2018 The Authors. Published by Innovare Academic Sciences Pvt Ltd. This is an open access article under the CC BY license (http://creativecommons. org/licenses/by/4. 0/) DOI: http://dx.doi.org/10.22159/ajpcr.2018.v11i9.27734

\section{INTRODUCTION}

Raktagata Vata means involvement of Rakta (blood) by vitiated Vayu. According to Ayurveda, the main function of Rakta is "Jivana (life)." Hence, it has been mentioned as a "Jiva" (life). When Rasa-Rakta Dhatu (plasma and blood) remains in their normalcy and cardiovascular system, mainly Sira (veins), Dhamani (arteries), and Hridaya (heart) stay put standard and perform their functions as a rule. Any abnormality of Rasa Rakta Dhatu affects the normal circulation of Rasa Rakta and ultimately results in the abnormality of the blood pressure by making additional pressure or less pressure on the Rakta Vahinies (arteries). Rasa Rakta Samvahana (circulation of plasma and blood) occurs simultaneously in the body [1]. Therefore, the effect of Rakta Dhatu on the blood pressure is equivalent as that of Rasa Dhatu. By aforesaid descriptions, it can be understood that mainly Hridaya (heart) and components residing in it, i.e., Prana Vata and Vyana Vata, Apana Vata, Sadhaka Pitta, Avalambaka Kapha, Oja (vital essence), and Rasa-Rakta Dhatus along with normal function of Mana (psyche) collectively help to maintain the physiology of the blood pressure. Mana (psyche) is a crucial factor in the development of various diseases. Manas Bhavas (psychological conditions) such as Lobha (greed), Krodha (anger), Shoka (grief), Bhaya (fear), Chinta (worry), and Udvega (anxiety) described in Ayurveda are responsible for the development of psychosomatic disorders. When these Manas Bhavas (emotional states) cross the physiological limit, considered as Manasika Vikaras (psychosomatic disorders) and now these are pathological state adversely affecting the mind and the body. In Ayurvedic text, no direct description is an available concern to hypertension, but on the basis of presenting symptoms, Raktagata Vata can be correlated with Uccharaktachapa (high blood pressure). It is a Vata Pitta Pradhana Tridoshaja Vyadhi [2]. Chronic diseases such as hypertension and diabetes mellitus are increasing at an epidemic extends all the way through the world due to unremitting constant alteration in the way of life pattern of human, which then advance go-ahead to high mortality rates.Even in India, hypertension affected $25 \%$ of urban and $33 \%$ of rural populations [3]. Hypertension is the term used to describe high blood pressure. Hypertension is one of the most common complex disorders. Blood pressure measures the force against the walls of arteries as the heart pumps blood through the body. Blood pressure readings are usually given as two numbers, for example, 120 over 80 (written as 120/80 mmHg). One or both of these numbers can be too high. The top number is the systolic blood pressure, and the bottom number is the diastolic blood pressure. Essential hypertension means that the cause of high blood pressure is not known. When plasma renin activity (PRA) is plotted against $24 \mathrm{~h}$ sodium excretion, $10-15 \%$ of hypertension patients have high PRA and $25 \%$ have low PRA. High-renin patients may have a vasoconstrictor form of hypertension since low-renin patients may have volumedependent hypertension [4]. The Chakras are vortices of Pranic energy (vital force or vital energy) at specific areas in the body which control the circulation of Prana. The centers of the Chakras are related to specific areas of the brain, and in most people, these psychic centers lie dormant and inactive stages. Concentration on the Chakras while performing Yogic practices stimulates the flow of energy through the Chakras and helps to activate them [5]. The literal meaning of Nadi is "flow," as the negative and positive forces of electricity flow through complex circuits, and in the same way, Prana Shakti (vital force) and Manas Shakti (mental force) flow through every part of our body through these Nadis. Various communications of these Nadis (nerves) form many networks (plexuses) that resemble like lotus. Hence, these Chakras are represented as the symbol of lotus with its petals. Agya Chakra is the sixth among seven major Chakras which is present behind the center of both eyebrows and belongs to the area forebrain to the midbrain. It is the chief controlling, balancing, and regulating center of the brain, including the cerebrum, thalamus, and hypothalamus [6]. 
Table 1: Hastapada Daha in Raktagata Vata in control and intervention subgroups before and after intervention

\begin{tabular}{|c|c|c|c|c|c|c|}
\hline \multirow[t]{2}{*}{ Subgroup } & \multicolumn{5}{|c|}{ Number and percentage of cases } & \multirow{2}{*}{$\begin{array}{l}\text { Within the subgroups comparison Friedman } \\
\text { test }\end{array}$} \\
\hline & Grade & BT (\%) & FU1 (\%) & FU2 (\%) & FU3 (\%) & \\
\hline \multirow[t]{3}{*}{ Control } & 0 & $00(00)$ & $04(16)$ & $07(28)$ & $13(52)$ & \multirow{3}{*}{$\begin{array}{l}\chi^{2}=69.344 \\
\mathrm{p}<0.001\end{array}$} \\
\hline & 2 & $06(24)$ & $03(12)$ & $04(16)$ & $03(12)$ & \\
\hline & 3 & $16(64)$ & $11(44)$ & $08(32)$ & $04(16)$ & \\
\hline \multirow[t]{4}{*}{ Intervention } & 0 & $00(0)$ & $05(20)$ & $10(40)$ & $22(88)$ & \multirow{6}{*}{$\begin{array}{l}\chi^{2}=71.127 \\
\mathrm{p}<0.001\end{array}$} \\
\hline & 1 & $02(08)$ & $07(28)$ & $09(36)$ & $02(08)$ & \\
\hline & 2 & $09(36)$ & $04(16)$ & $02(08)$ & $01(04)$ & \\
\hline & 3 & $14(56)$ & $09(36)$ & $04(16)$ & $00(0)$ & \\
\hline \multirow{2}{*}{\multicolumn{2}{|c|}{$\begin{array}{l}\text { Between the subgroups } \\
\text { comparison Chi-square test }\end{array}$}} & $\chi^{2}=0.933$ & $\chi^{2}=0.359$ & $\chi^{2}=3.130$ & $\chi^{2}=8.100$ & \\
\hline & & $\mathrm{p}=0.627$ & $\mathrm{p}=0.836$ & $\mathrm{p}=0.372$ & $\mathrm{p}=0.017$ & \\
\hline
\end{tabular}

Table 2: Klama in Raktagata Vata in control and intervention subgroups before and after intervention

\begin{tabular}{|c|c|c|c|c|c|c|}
\hline \multirow[t]{2}{*}{ Subgroup } & \multicolumn{5}{|c|}{ Number and percentage of cases } & \multirow{2}{*}{$\begin{array}{l}\text { Within the subgroups comparison Friedman } \\
\text { test }\end{array}$} \\
\hline & Grade & BT (\%) & FU1 (\%) & FU2 (\%) & FU3 (\%) & \\
\hline \multirow[t]{4}{*}{ Control } & 0 & $00(0)$ & $03(12)$ & $07(28)$ & $16(64)$ & \multirow{4}{*}{$\begin{array}{l}\chi^{2}=72.350 \\
\mathrm{p}<0.001\end{array}$} \\
\hline & 1 & $01(4)$ & $04(16)$ & $08(32)$ & $03(12)$ & \\
\hline & 2 & $07(28)$ & $06(24)$ & $03(12)$ & $02(08)$ & \\
\hline & 3 & $17(68)$ & $12(48)$ & $08(32)$ & $04(16)$ & \\
\hline \multirow[t]{3}{*}{ Intervention } & 0 & $00(0)$ & $06(24)$ & $08(32)$ & $20(80)$ & \multirow{5}{*}{$\begin{array}{l}\chi^{2}=61.873 \\
\mathrm{p}<0.001\end{array}$} \\
\hline & 2 & $06(24)$ & $03(12)$ & $01(04)$ & $01(04)$ & \\
\hline & 3 & $16(64)$ & $10(40)$ & $04(16)$ & $02(08)$ & \\
\hline \multirow{2}{*}{\multicolumn{2}{|c|}{$\begin{array}{l}\text { Between the subgroups } \\
\text { comparison Chi-square test }\end{array}$}} & $\chi^{2}=1.11$ & $\chi^{2}=2.50$ & $\chi^{2}=3.18$ & $\chi^{2}=1.59$ & \\
\hline & & $\mathrm{p}=0.575$ & $\mathrm{p}=0.287$ & $\mathrm{p}=0.364$ & $\mathrm{p}=0.208$ & \\
\hline
\end{tabular}

*Data available for 50 participants

Table 3: Hridadrava in Raktagata Vata in control and intervention subgroups before and after intervention

\begin{tabular}{|c|c|c|c|c|c|c|}
\hline \multirow[t]{2}{*}{ Subgroup } & \multicolumn{5}{|c|}{ Number and percentage of cases } & \multirow{2}{*}{$\begin{array}{l}\text { Within the subgroups comparison Friedman } \\
\text { test }\end{array}$} \\
\hline & Grade & BT (\%) & FU1 (\%) & FU2 (\%) & FU3 (\%) & \\
\hline \multirow[t]{3}{*}{ Control } & 0 & $05(20)$ & $04(16)$ & $09(36)$ & $15(60)$ & \multirow{3}{*}{$\begin{array}{l}\chi^{2}=53.765 \\
p<0.001\end{array}$} \\
\hline & 2 & $13(52)$ & $08(32)$ & $07(28)$ & $03(12)$ & \\
\hline & 3 & $03(12)$ & $03(12)$ & $02(08)$ & $02(08)$ & \\
\hline \multirow[t]{4}{*}{ Intervention } & 0 & $04(16)$ & $07(0)$ & $13(52)$ & $20(80)$ & \multirow{6}{*}{$\begin{array}{l}\chi^{2}=34.324 \\
\mathrm{p}<0.001\end{array}$} \\
\hline & 1 & $07(28)$ & $09(0)$ & $06(24)$ & $02(08)$ & \\
\hline & 2 & $08(32)$ & $05(0)$ & $03(12)$ & $01(04)$ & \\
\hline & 3 & $06(24)$ & $04(0)$ & $03(12)$ & $02(08)$ & \\
\hline \multirow{2}{*}{\multicolumn{2}{|c|}{$\begin{array}{l}\text { Between the subgroups } \\
\text { comparison Chi-square test }\end{array}$}} & $\chi^{2}=4.091$ & $\chi^{2}=2.179$ & $\chi^{2}=1.026$ & $\chi^{2}=1.020$ & \\
\hline & & $\mathrm{p}=0.252$ & $\mathrm{p}=0.336$ & $\mathrm{p}=0.599$ & $\mathrm{p}=0.3121$ & \\
\hline
\end{tabular}

*Data available for 50 participants

Therefore, Nadi Shodhana is a practice whereby the Pranika channels are purified and regulated. This prepares one for the practice of other Pranayama so that maximum benefits can be derived and one does not experience any Pranika imbalance. The breathing technique is named Nadi Shodhana, as it helps clear out blocked energy channels in the body, which in turn calms the mind. It is also known as Anuloma Viloma Pranayama. An unbroken flow of knowledge in particular object is Dhyana. The mind tries to think of one object, to hold itself to one particular spot, at the top of the head, the heart, etc.,and if the mind succeeds in receiving the sensations only through that particular part of the body, and not from any other part, called Dharana (concentration), and Dhyana (meditation) is a condition in which the mind succeeds in keeping it in that state for some time [7].

\section{METHODS}

\section{Ethics}

This study was started after permission of the institutional ethical committee agree with ethical standards.

\section{Study design}

To study the effect of Pranayama, especially, Nadi Shodhana Pranayama (NSP) with Dhyana in stress-induced Raktagata Vata (essential hypertension), a total of 50 cases were registered (random selection). These all were divided into two subgroups consisting 25 cases in each.

I. Control - only Yogic practices were done.

II. Intervention - 25 cases in this group practice of NSP and Dhyana (meditation) for 3 months. Very light medications of first order primarily also prescribed which were withdrawn later (after 1 month).

These cases practice Yogic exercises 2 times in the morning and evening for 3 months. At the end of 3 months, a comparison was done and observations were analyzed using statistical methods.

\section{Exclusion criteria}

The following criteria were excluded from the study:

- Patient with comorbidity affecting mental or physical health 
Table 4: Svayathu in Raktagata Vata in control and intervention subgroups before and after intervention

\begin{tabular}{|c|c|c|c|c|c|c|}
\hline \multirow[t]{2}{*}{ Subgroup } & \multicolumn{5}{|c|}{ Number and percentage of cases } & \multirow{2}{*}{$\begin{array}{l}\text { Within the subgroups comparison Friedman } \\
\text { test }\end{array}$} \\
\hline & Grade & BT (\%) & FU1 (\%) & FU2 (\%) & FU3 (\%) & \\
\hline \multirow[t]{4}{*}{ Control } & 0 & $12(48)$ & $14(56)$ & $12(48)$ & $14(56)$ & \multirow{4}{*}{$\begin{array}{l}\chi^{2}=4.714 \\
p=0.194\end{array}$} \\
\hline & 1 & $06(24)$ & 05 (20) & 08 (32) & $06(24)$ & \\
\hline & 2 & 04 (16) & 03 (12) & 02 (08) & 03 (12) & \\
\hline & 3 & 03 (12) & 03 (12) & 03 (12) & 02 (08) & \\
\hline \multirow[t]{4}{*}{ Intervention } & 0 & $14(56)$ & $12(48)$ & 17 (68) & $19(76)$ & \multirow{6}{*}{$\begin{array}{l}\chi^{2}=6.429 \\
p=0.093\end{array}$} \\
\hline & 1 & 02 (08) & $06(24)$ & 02 (08) & 03 (12) & \\
\hline & 2 & 05 (20) & 03 (12) & 03 (12) & $01(04)$ & \\
\hline & 3 & 04 (16) & 04 (16) & 03 (12) & 02 (08) & \\
\hline \multirow{2}{*}{\multicolumn{2}{|c|}{$\begin{array}{l}\text { Between the subgroups } \\
\text { comparison Chi-square test }\end{array}$}} & $\chi^{2}=2.410$ & $\chi^{2}=0.322$ & $\chi^{2}=4.550$ & $\chi^{2}=2.206$ & \\
\hline & & $\mathrm{p}<0.492$ & $\mathrm{p}<0.851$ & $\mathrm{p}<0.103$ & $\mathrm{p}<0.322$ & \\
\hline
\end{tabular}

*Data available for 50 participants

Table 5: Shirahshula in Raktagata Vata in control and intervention subgroups before and after intervention

\begin{tabular}{|c|c|c|c|c|c|c|}
\hline \multirow[t]{2}{*}{ Subgroup } & \multicolumn{5}{|c|}{ Number and percentage of cases } & \multirow[t]{2}{*}{ Within the subgroups comparison Friedman test } \\
\hline & Grade & BT (\%) & FU1 (\%) & FU2 (\%) & FU3 (\%) & \\
\hline \multirow[t]{4}{*}{ Control } & 0 & $00(0)$ & $04(16)$ & $08(32)$ & $13(52)$ & \multirow{4}{*}{$\begin{array}{l}\chi^{2}=72.217 \\
\mathrm{p}<0.001\end{array}$} \\
\hline & 1 & $02(08)$ & 03 (12) & $01(04)$ & 02 (08) & \\
\hline & 2 & $04(16)$ & $04(16)$ & $06(24)$ & $04(16)$ & \\
\hline & 3 & $19(76)$ & $14(56)$ & $10(40)$ & $06(24)$ & \\
\hline \multirow[t]{4}{*}{ Intervention } & 0 & $00(0)$ & 07 (28) & $12(48)$ & $22(88)$ & \multirow{6}{*}{$\begin{array}{l}\chi^{2}=74.198 \\
\mathrm{p}<0.001\end{array}$} \\
\hline & 1 & $01(04)$ & 03 (12) & $04(16)$ & $01(04)$ & \\
\hline & 2 & $04(16)$ & 03 (12) & 02 (08) & $00(0)$ & \\
\hline & 3 & $20(80)$ & $12(48)$ & 07 (28) & $02(08)$ & \\
\hline \multirow{2}{*}{\multicolumn{2}{|c|}{$\begin{array}{l}\text { Between the subgroups } \\
\text { comparison - Chi-square test }\end{array}$}} & $\chi^{2}=0.117$ & $\chi^{2}=1.050$ & $\chi^{2}=1.410$ & $\chi^{2}=17.56$ & \\
\hline & & $p=0.733$ & $\mathrm{p}=0.592$ & $\mathrm{p}=0.495$ & $\mathrm{p}=0.005$ & \\
\hline
\end{tabular}

*Data available for 50 participants

Table 6: Krodhi Svabhava in Raktagata Vata in control and intervention subgroups before and after intervention

\begin{tabular}{|c|c|c|c|c|c|c|}
\hline \multirow[t]{2}{*}{ Subgroup } & \multicolumn{5}{|c|}{ Number and percentage of cases } & \multirow{2}{*}{$\begin{array}{l}\text { Within the subgroups comparison Friedman } \\
\text { test }\end{array}$} \\
\hline & Grade & BT (\%) & FU1 (\%) & FU2 (\%) & FU3 (\%) & \\
\hline \multirow[t]{4}{*}{ Control } & 0 & $01(04)$ & $04(16)$ & $10(40)$ & $15(60)$ & \multirow{4}{*}{$\begin{array}{l}\chi^{2}=66.818 \\
p<0.001\end{array}$} \\
\hline & 1 & 03 (12) & 07 (28) & 03 (12) & $04(16)$ & \\
\hline & 2 & $05(20)$ & $06(24)$ & $04(16)$ & 02 (08) & \\
\hline & 3 & $16(64)$ & $08(32)$ & $08(32)$ & $04(16)$ & \\
\hline \multirow[t]{4}{*}{ Intervention } & 0 & $00(0)$ & $06(24)$ & $16(64)$ & $22(88)$ & \multirow{6}{*}{$\begin{array}{l}\chi^{2}=68.044 \\
p<0.001\end{array}$} \\
\hline & 1 & 03 (12) & 03 (12) & $00(0)$ & $01(04)$ & \\
\hline & 2 & $04(16)$ & $06(24)$ & $03(12)$ & $02(08)$ & \\
\hline & 3 & $18(72)$ & $10(40)$ & $06(24)$ & $00(0)$ & \\
\hline \multirow{2}{*}{\multicolumn{2}{|c|}{$\begin{array}{l}\text { Between the subgroups } \\
\text { comparison Chi-square test }\end{array}$}} & $\chi^{2}=0.368$ & $\chi^{2}=0.422$ & $\chi^{2}=3.270$ & $\chi^{2}=5.090$ & \\
\hline & & $\mathrm{p}=0.544$ & $\mathrm{p}=0.810$ & $\mathrm{p}=0.195$ & $\mathrm{p}=0.024$ & \\
\hline
\end{tabular}

*Data available for 50 participants

- Patient with extreme age groups $>65$ years or $<15$ years

- Abuse of drugs and alcohol

- Patients with terminal illness or advanced state of disease.

\section{Inclusion criteria}

The following criteria were included in the study:

- Patients and healthy male and female volunteers between the age group of 15 and 65 years.

- Patients diagnosed with irregular menstrual cycle, chronic pelvic pain, and stress and anxiety.

- Patients with chronic headache with a history of stress.

Statistical methods

We applied paired and unpaired Friedman's test, Chi-square test, and Wilcoxon signed-rank test to assess the changes in the quantitative variables and symptoms from baseline to different sequences of followup. We used SPSS 16 software to analyze the study. $p>0.05$ indicates insignificant result and $\mathrm{p}<0.05$ indicates the significant result. $\mathrm{p}<0.001$ indicates the highly significant result.
Diagnostic criteria of Raktagata Vata

Shiroruk (headache), Aruchi (anorexia), Bhrama (giddiness), Prabhuta Mutrata (polyurea), Tamodarshana (flashes before eyes), Nidra Nasha (insomnia), Ati Daurbalya (weakness), Krodha Prachurata (anger), Klama (easy fatigability), Smritihrasha (forgetfulness), Hrid drava (palpitation), and Svash krichrata (breathlessness) were included as the symptoms of Raktagata Vata [8]. Recent national guidelines, known as the Seventh Report of the Joint National Committee (JNC) on prevention, detection, evaluation, and treatment of high blood pressure (JNC7), suggest a more forceful move toward to detect and treat the hypertension. According to this classification, normal systolic pressure and diastolic blood pressure in adult are 12-15.9 and 8.0-10.5 $\mathrm{kPa}\left(\mathrm{kN} / \mathrm{m}^{2}\right)$, respectively. A condition in which systolic and diastolic blood pressure is measured as $16.1-18.5$ and $10.8-11.9 \mathrm{kPa}\left(\mathrm{kN} / \mathrm{m}^{2}\right)$ is known as pre-hypertensive condition. If the blood pressure is more than these above values, is called hypertension [9].The Hamilton's anxiety rating scale (HARS) is one of the first rating scales developed to measure the severity of anxiety symptoms and is used in both clinical and research settings. The scale consists of 14 items, each defined by a series of symptoms, and measures 
Table 7: Nidranasha in Raktagata Vata in control and intervention subgroups before and after intervention

\begin{tabular}{|c|c|c|c|c|c|c|}
\hline \multirow[t]{2}{*}{ Subgroup } & \multicolumn{5}{|c|}{ Number and percentage of cases } & \multirow[t]{2}{*}{ Within the subgroups comparison Friedman test } \\
\hline & Grade & BT & FU1 & FU2 & FU3 & \\
\hline \multirow[t]{3}{*}{ Control } & 0 & $00(0)$ & $02(08)$ & $06(24)$ & $16(64)$ & \multirow{3}{*}{$\begin{array}{l}\chi^{2}=66.380 \\
\mathrm{p}<0.001\end{array}$} \\
\hline & 2 & $12(48)$ & $07(28)$ & $05(20)$ & $03(12)$ & \\
\hline & 3 & $13(52)$ & $10(40)$ & $07(28)$ & $05(20)$ & \\
\hline \multirow[t]{4}{*}{ Intervention } & 0 & $00(0)$ & $05(20)$ & $09(36)$ & $18(72)$ & \multirow{6}{*}{$\begin{array}{l}\chi^{2}=72.163 \\
p<0.001\end{array}$} \\
\hline & 1 & $02(08)$ & $03(12)$ & $03(12)$ & 03 (12) & \\
\hline & 2 & $08(32)$ & $06(24)$ & 04 (16) & 02 (08) & \\
\hline & 3 & $15(60)$ & $11(44)$ & $09(36)$ & $02(08)$ & \\
\hline \multirow{2}{*}{\multicolumn{2}{|c|}{$\begin{array}{l}\text { Between the subgroups } \\
\text { comparison - Chi-square test }\end{array}$}} & $\chi^{2}=2.940$ & $\chi^{2}=0.125$ & $\chi^{2}=3.410$ & $\chi^{2}=1.590$ & \\
\hline & & $\mathrm{p}=0.230$ & $\mathrm{p}=0.940$ & $\mathrm{p}=0.182$ & $\mathrm{p}<0.208$ & \\
\hline
\end{tabular}

*Data available for 50 participants

Table 8: Bhrama in Raktagata Vata in control and intervention subgroups before and after intervention

\begin{tabular}{|c|c|c|c|c|c|c|}
\hline \multirow[t]{2}{*}{ Subgroup } & \multicolumn{5}{|c|}{ Number and percentage of cases } & \multirow{2}{*}{$\begin{array}{l}\text { Within the subgroups comparison Friedman } \\
\text { test }\end{array}$} \\
\hline & Grade & BT (\%) & FU1 (\%) & FU2 (\%) & FU3 (\%) & \\
\hline \multirow[t]{3}{*}{ Control } & 0 & $04(16)$ & $05(20)$ & $09(36)$ & $15(60)$ & \multirow{3}{*}{$\begin{array}{l}\chi^{2}=55.810 \\
\mathrm{p}<0.001\end{array}$} \\
\hline & 2 & $11(44)$ & $08(32)$ & $06(24)$ & $04(16)$ & \\
\hline & 3 & $06(24)$ & $04(16)$ & $03(12)$ & $02(08)$ & \\
\hline \multirow[t]{4}{*}{ Intervention } & 0 & $02(08)$ & $07(28)$ & $12(48)$ & $20(80)$ & \multirow{6}{*}{$\begin{array}{l}\chi^{2}=61.470 \\
\mathrm{p}<0.001\end{array}$} \\
\hline & 1 & $08(32)$ & $09(36)$ & $08(32)$ & $02(08)$ & \\
\hline & 2 & $11(44)$ & $06(24)$ & $03(12)$ & $02(08)$ & \\
\hline & 3 & $04(16)$ & $03(12)$ & $02(08)$ & $01(04)$ & \\
\hline \multirow{2}{*}{\multicolumn{2}{|c|}{$\begin{array}{l}\text { Between the subgroups } \\
\text { comparison Chi-square test }\end{array}$}} & $\chi^{2}=2.400$ & $\chi^{2}=0.821$ & $\chi^{2}=1.64$ & $\chi^{2}=2.380$ & \\
\hline & & $\mathrm{p}=0.494$ & $\mathrm{p}=0.845$ & $\mathrm{p}=0.441$ & $\mathrm{p}=0.123$ & \\
\hline
\end{tabular}

*Data available for 50 participants

Table 9: Raktamukhanetrata in Raktagata Vata in control and intervention subgroups before and after intervention

\begin{tabular}{|c|c|c|c|c|c|c|}
\hline \multirow[t]{2}{*}{ Subgroup } & \multicolumn{5}{|c|}{ Number and percentage of cases } & \multirow{2}{*}{$\begin{array}{l}\text { Within the group comparison Friedman } \\
\text { test }\end{array}$} \\
\hline & Grade & BT (\%) & FU1 (\%) & FU2 (\%) & FU3 (\%) & \\
\hline \multirow[t]{4}{*}{ Control } & 0 & $01(04)$ & $07(28)$ & $10(40)$ & $16(64)$ & \multirow{4}{*}{$\begin{array}{l}\chi^{2}=55.810 \\
p<0.001\end{array}$} \\
\hline & 1 & $08(32)$ & $08(32)$ & $07(28)$ & $05(20)$ & \\
\hline & 2 & $13(52)$ & $08(32)$ & $06(24)$ & $03(12)$ & \\
\hline & 3 & $03(12)$ & $02(08)$ & $02(08)$ & $01(04)$ & \\
\hline \multirow[t]{4}{*}{ Intervention } & 0 & $00(0)$ & $09(36)$ & $16(64)$ & $21(84)$ & \multirow{6}{*}{$\begin{array}{l}\chi^{2}=63.386 \\
\mathrm{p}<0.001\end{array}$} \\
\hline & 1 & $11(44)$ & $05(20)$ & $03(12)$ & $03(12)$ & \\
\hline & 2 & $09(36)$ & $08(32)$ & $04(14)$ & $01(04)$ & \\
\hline & 3 & $05(20)$ & $03(12)$ & $02(08)$ & $00(0)$ & \\
\hline \multirow{2}{*}{\multicolumn{2}{|c|}{$\begin{array}{l}\text { Between the group } \\
\text { comparison Chi-square test }\end{array}$}} & $\chi^{2}=1.430$ & $\chi^{2}=1.140$ & $\chi^{2}=3.380$ & $\chi^{2}=2.600$ & \\
\hline & & $\mathrm{p}=0.490$ & $\mathrm{p}=0.767$ & $\mathrm{p}=0.336$ & $\mathrm{p}=0.107$ & \\
\hline
\end{tabular}

*Data available for 50 participants

Table 10: HARS grading in Raktagata Vata in control and intervention subgroups before and after intervention

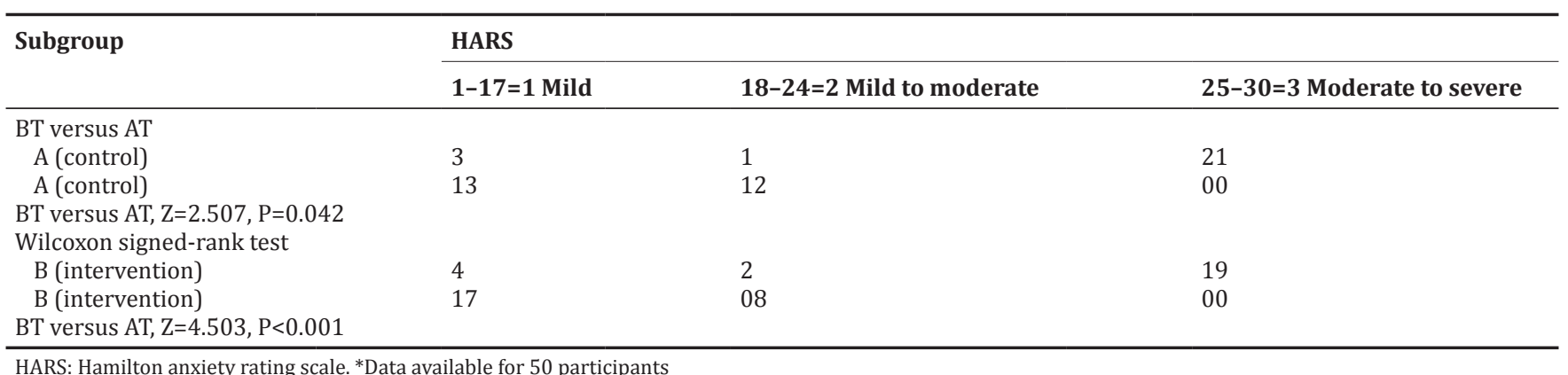

both psychic anxiety (mental agitation and psychological distress) and somatic anxiety (physical complaints related to anxiety). Each item is scored on a scale of 0 (not present) to 4 (severe), with a total score range of $0-56$, where $<17$ indicates mild severity, 18-24 mild-to-moderate severity, and 25-30 moderate-to-severe [10].

\section{OBSERVATION AND RESULTS}

The majority of registered cases of Raktagata Vata were male (56\%) followed by female (44\%). Most of the participants were of middle class (40.0\%), followed by upper and lower class (30.0\%). Most of the 
participants were of Vataja-Pittaja Deha Prakriti (60\%) followed by Vataja-Kaphaja Deha Prakriti (30\%).

Results also signified that initially mean \pm SD in reference to systolic blood pressure, diastolic blood pressure, and mean blood pressure inintervention subgroup was $154.56 \pm 10.607,107.52 \pm 20.157$, and $117.007 \pm 6.616$ that became $126.80 \pm 8.60,95.520 \pm 6.739$, and $107.48 \pm 6.199$ after third followup statistically highly significant $(\mathrm{p}<0.001)$.

Results signified that initially mean \pm SD in reference to systolic blood pressure, diastolic blood pressure, and mean blood pressure in control subgroup was $161.84 \pm 8.716,98.880 \pm 5.540$, and $122.59 \pm 7.534$ that became $148.72 \pm 9.79,91.440 \pm 5.874$, and $113.40 \pm 7.382$ after third follow-up statistically highly significant $(\mathrm{p}<0.001)$. All the Tables $1-10$ signify that better results were found in minimizing the symptoms of Raktagata Vata in intervention than control.

\section{DISCUSSION}

Yoga is a physical and spiritual exercise regimen cling to enormous potential as a cointervention in the enhancement in the quality of life. It involves a variety of body postures and activities (known as Asanas), breathing techniques, and meditation, which are all planned to encourage physical comfort and mental calm [11]. The most prominent disorder of psychosomatic disorders is a disturbance of sleep. The bad effect is due to longtime secretion of stress-induced hormone (catecholamine), i.e., cortisol and adrenaline. During the relax stage, the body performs many anabolic reactions which are valuable for the regulation and proper functioning of body and mind (psychosomatic) physiology. Any commotion in the pattern and duration of sleep breaks up so many metabolic chain reaction cycles. By the result of this, a lot of intermediate by-products form, known as metabolic by-products. These metabolic by-products work as harmful substances in the body and some of themform free radicals, dangerous for our physiological systems. In the present scenario, the chief causes of psychosomatic disorders are not the proper welfare in the perspective of physical, mental, social, and spiritual. Main balancers of psychosomatic activities are an autonomic nervous system (ANS) and the endocrine system. Both the systems work together in the control of cerebral thalamohypophysial axis [12].

Both Yogic practice NSP and Dyana (meditation) work together beautifully. Pranayama is the preliminary step of the meditation. Pranayama breathing is defined as the manipulation of breath movements. Its alternate breathing pattern controls the action of the opposite half of the cerebrum hemisphere. Through this, Pranayama can develop a control over stress-induced irregulation of the ANS. Any internal thought or imaginary thinking induced psychic response activates and stimulates the ANS, which starts safety mechanism to accommodate physiological activities of the different system. One prior study was carried out on 50 cases in the Department of Physiology, S. Nijalingappa Medical College, Bagalkot, Karnataka, India. There was a significant reduction in pulse rate, systolic blood pressure, diastolic blood, pressure and mean arterial blood pressure after practicing meditation and Pranayama for 15 days [13]. Another study also carried out on 30 patients. The study showed a significant fall of mean blood pressure after 3 months of Yoganidra [14].

Physiology of ANS regarding stress

Any stress-induced psychic activity as anger, anxiety, jealousy, hate, and ego stimulates the ANS (body alarming and balancing and alarming system) which performs stimulatory and inhibitory action both through hypothalamic pituitary axis (HPA). Stimulation of sympathetic centers causes increased heart rate, force of contraction, constriction of most viscera and skin, dilatation of blood vessels of the heart, lungs, brain and skeletal muscle, dilatation of the airways, conversion of glycogen into glucose, decrease in digestive activity, water retention, and elevated blood pressure. On the other hand, stimulation of anterior pituitary stimulates adrenal cortex, thyroid, and liver, leading to

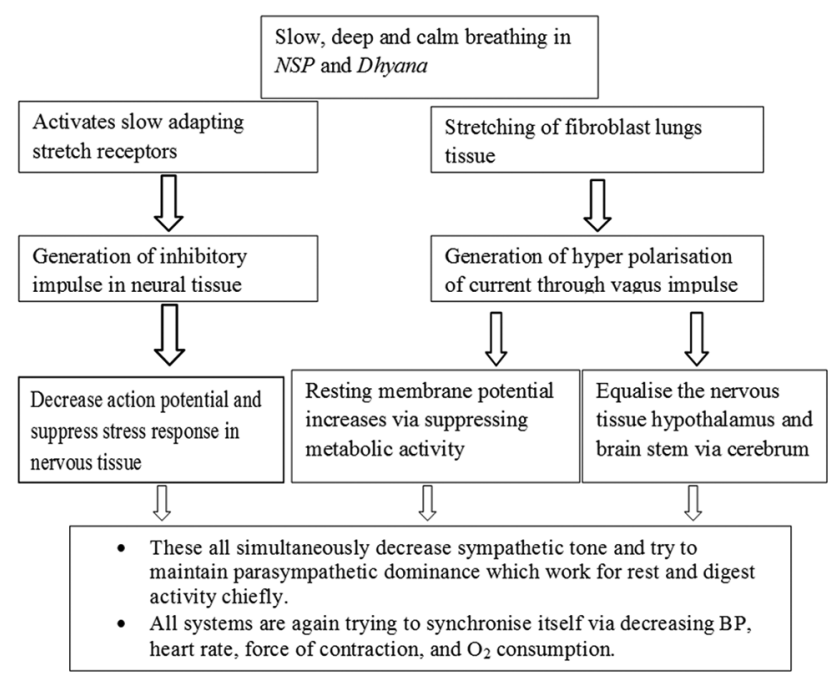

Fig. 1: The autonomic shift

lipolysis, glycogenolysis, and increased protein catabolism, through a maximum utilization of glucose to produce ATP $[15,16]$. Yogic practices (NSP and meditation) harmonize the action of stress-induced reaction through balancing the ANS. Agya Chakra is supposed to chief governing Chakra in Chakral system of Nadis. All the parts of these Chakras include cerebral hemisphere, thalamus, hypothalamus functionary unit's pituitary, and pineal glands. Regulation of respiratory rhythm through inhibitory response shifted sympathetic tone to parasympathetic and tried to synchronize the action of HPA axis $[6,17]$. In one prior study, female subjects suffering from mental distress showed significant improvement in perceived stress $(p<0.02)$, depression $(p<0.05)$, state and trait anxiety $(p<0.02$ and 0.01$)$, well-being $(p<0.01)$, physical wellbeing $(p<0.01)$, and vigor $(p<0.02)$. In summary, this study provides preliminary evidence that integrated Yoga therapy can be an effective treatment for stress-induced hypertension [18].

\section{Physiology of NSP and Dhyana}

NSP unique method results in balancing the ANS and influences psychosomatic and stress-related disorders. Mechanisms behind it are NSP which causes a state of calm attentiveness by increasing parasympathetic drive, calming of stress reaction, releasing of hormones at neuroendocrine level, and releasing of thalamic generators. This study was carried out to assess the changes in baseline metabolic and autonomic reactions happening in Raktagata Vata by practicing NSP. A continuous flow of knowledge to a particular object is known as Dhyana. Dhyana is considered as a way of negation of the world, as in Yoga Sutra, Dhyana is an uninterrupted flow of mind toward the objects chosen for the meditation $[19,20]$. Autonomic shift occurs during the practices of slow breathing Pranayama and Dhyana (Fig. 1) [21,22].

\section{CONCLUSION}

Agya Chakra is the chief controlling center for most of the self-regulated psychophysiological activities. It develops a control over these activities through cerebro-thalamo-hypophysial axis. It is the main center of meditation by which regular practitioner can modify and refine his cognition power, memory, and intellect word speech and formation ability. Through Yogic practices (NSP and Dhyana) at the region of Agya Chakra, person can develop the capability of shifting of involuntary actions to voluntary or shifting of sympathetic to parasympathetic via developing a psychological control over cerebro thalamo limbic system.

\section{AUTHORS' CONTRIBUTION}

The conception and design of the study: Awasthi H.H, Mishra V.N. Experimental work and collection of data: Pal Pradeep Kumar. Preparation of manuscript: Saini Neera. 


\section{CONFLICTS OF INTEREST}

All the authors related to this manuscript declared that they have no conflicts of interest

\section{REFERENCES}

1. Dwivedi BK, Goswami P. Charak Samhita, Chikitsa Sthana 3/114. $1^{\text {st }}$ ed. Varanasi: Chaukhambha Krishna Das Academy; 2013.

2. Available from: http://www.emedicine.Medscap.com/article/hypertension.

3. Jhawat V, Gupta S, Bimal KA, Roy P, Saini V. Prevalence and risk factors of essential hypertension and new onset of diabetes in essential hypertension in rural population of Haryana. Int $\mathrm{J}$ Pharm Pharm Sci 2018;7:142-8.

4. Available from: http://www.ancientayurved.com/diseases/hypertension.

5. Swami SS. Kundilini Tantra. Bihar: Yoga Publication Trust; 2009.

6. Rishi N. Ajna Chakra. $1^{\text {st }}$ ed. Bihar: Yoga publication trust; 2010.

7. Swami SS. Asana Pranayama Mudra Bandha. Bihar: Yoga publication trust; 2009.

8. Swami N. Prana and Pranayam. $1^{\text {st }}$ ed. Bihar: Yoga Publication Trust; 2008.

9. Available from: http://www.nhlbi.nih.gov/files/docs/guidelines/phycard.pdf.

10. Hamilton M. The assessment of anxiety states by rating. Br J Med Psychol 1959;32:50-5

11. Kalsi A, Singh S, Taneja N, Kukal S, Mani S. Current treatments for Type 2 diabetes, their side effects and possible complementary treatments. Int J Pharm Pharm Sci 2015;7:13-8.

12. Stanley L. Psychosomatic illness. Available from: http://www.cyc-net. org/reference/refs-psychosomatic-levenstein.html

13. Ankad RB, Herur A, Patil S, Shashikala GV, Chinagudi S. Effect of short-term pranayama and meditation on cardiovascular functions in healthy individuals. Heart Views 2011;12:58-62.

14. Deepa T, Sethu G, Thirrunavukkarasu N. Effect of yoga and meditation on mild to moderate essential hypertensives. J Clin Diagn Res 2012;6:21-6.

15. Gerard JT. Principle of Anatomy and Physiology. $12^{\text {th }}$ ed. America: Hoboken; 2009.

16. Davidson S. Principal and practice of Medicine. 20 $0^{\text {th }}$ ed. British: Churchill Livingstone; 2006.

17. Motoyama H. Theories of the Chakras (Bridge of higher consciousness). $1^{\text {st }}$ ed. Delhi: New Age Books; 2001.

18. Michalsen A, Grossman P, Acil A, Langhorst J, Lüdtke R, Esch T, et al. Rapid stress reduction and anxiolysis among distressed women as a consequence of a three-month intensive yoga program. Med Sci Monit 2005;11:CR555-561.

19. Subbalakshmi NK, Saxena SK, Urmimala D. Immediate effect of "nadishodhana pranayama" on some selected parameters of cardiovascular, pulmonary, and higher functions of brain. Thai J Physiol Sci 2005;18:10-6.

20. Iyenger BK. Light on Pranayama-Pranayama Dipika. $20^{\text {th }}$ ed. New Delhi: Harper Collins publishers; 2006.

21. Uddupa KN. A Manual of Science and Philosophy of Yoga. $1^{\text {st }}$ ed. Varanasi: Sarvodaya Sahitya Prakashan; 1995.

22. Singh RH. Yoga Evam Yogic Chikitsa. ${ }^{\text {st }}$ ed. Delhi: Chaukhamba Sanskrita Pratisthan; 1994. 